\title{
CO-INFECTION OF DENGUE VIRUS BY SEROTYPES 3 AND 4 IN PATIENTS FROM AMAZONAS, BRAZIL
}

Regina M.P. de FIGUEIREDO(1), Felipe Gomes NAVECA(2), Cintia Mara OLIVEIRA(1), Michele de Souza BASTOS(1), Maria Paula Gomes MOURÃO(1), Suziane de S. VIANA(1), Miriam do N. MELO(1), Evaulino F. ITAPIREMA(1), Cassiano J. SAATKAMP(1) \& Izeni P. FARIAS(3)

\begin{abstract}
SUMMARY
The natural co-infection with dengue virus can occur in highly endemic areas where different serotypes have been observed for many years. We report here four cases of DENV-3/DENV-4 co-infection detected by serological and molecular tests among 674 patients with acute undifferentiated fever from the tropical medicine reference center of Manaus City, Brazil, between 2005 and 2010. Analysis of the sequences obtained indicated the presence of genotype 3 and 1 for DENV-3 and DENV-4 respectively.
\end{abstract}

KEYWORDS: Brazil; Dengue; Co-infection; Flavivirus.

Dengue Fever is the most important arboviral disease worldwide. Dengue viruses (DENVs) belong to the genus Flavivirus, family Flaviviridae. These are single-stranded positive-sense RNA viruses grouped into four antigenically related, but distinct, serotypes named DENV-1, 2, 3 and $4^{5}$. Since the first laboratory-confirmed DENV cases at Roraima 1981-1982, more than four million cases of dengue have been reported in Brazil ${ }^{11}$. In Manaus, the capital of the Amazonas State in Brazil, all four dengue serotypes have already been reported ${ }^{3,4}$. Dengue virus co-infection cases are poorly documented in literature, although our results demonstrate that such cases might be more common than expected, mostly in hyperendemic areas.

From January 2005 to December 2010, 674 patients with acute undifferentiated fever were treated at a reference center of Tropical Medicine (Fundação de Medicina Tropical Doutor Heitor Vieira Dourado - FMT-HVD, Manaus, Brazil). These patients were tested for malaria by thick blood analyses, and all patients with negative results were asked to participate in this study. The participants signed an informed consent form that was approved by the FMTAM Ethical Committee Board (272/2005). Two blood samples were collected from each patient, one in the acute phase of the disease and the other in the convalescent form. Sera from the convalescent phase were used for detection of antidengue immunoglobulin M (IgM) specific antibodies by MAC-ELISA, as previously described ${ }^{9}$.

Acute-phase samples were used in two tests: one for viral isolation in C6/36 Aedes albopictus cell line, followed by viral identification using an indirect immunofluorescent test with dengue type-specific monoclonal antibodies ${ }^{7}$, kindly provided by Centers for Disease Control and Prevention (CDC), Atlanta, Georgia USA; and the other for specific DENV nucleic acid amplification. RNA was extracted directly from serum samples with the QIAamp Viral RNA Mini-Kit (Qiagen, USA), following manufacturer's instructions and submitted to RT-PCR to be followed by semi-nested multiplex PCR as previously described for DENV detection and typing ${ }^{10}$. When samples were positive for any serotype of DENV, a second semi-nested PCR, this time in a singleplex format, with a type-specific primer (DENV-1 to DENV-4) was performed for confirmation. Amplicons from the $\mathrm{C} / \mathrm{PrM}$ region were purified and sequenced in both directions by using the BigDye Terminator Cycle Sequence Kit (Applied Biosystems, USA). The genotypes were detected by a search tool http://www.denguedb.org/submitGenotypeRequest. aspx?type=Dengue.

One hundred and thirty-five samples were positive for DENV: 2 DENV-1, 25 DENV-2, 71 DENV-3 and 37 for DENV-4. Four individuals, three women and one man, ages 40-70 years, had co-infections of DENV3 and 4 detected by immunofluorescence assay, RT-PCR and nucleotide sequencing (Table 1). Co-infections including distinct dengue serotypes are, probably, more common in tropical regions of the world where dengue is hyperendemic, with circulation of the four serotypes ${ }^{8}$. Risk factors for dengue infections and co-infections include the virulence of the virus and the density of Aedes ${ }^{6}$. Larval Index Rapid Assay (LIRA) varied from 2.6 to $2.8 \%$ between 2005 and 2007 (Table 1). In 2008, DENV-4 was reported in Brazil after 25 years of absence 4 . Although the paper was published in 2008, the DENV-4 positive samples were, in fact, obtained in 2005 and 2006, kept at $-80^{\circ} \mathrm{C}$ in FMT-HVD fever serum collection and analyzed in the second half of the year 2007 (Figueiredo, R.M. personal communication), which indicates that DENV-4 might have

(1) Fundação de Medicina Tropical Doutor Heitor Vieira Dourado, Manaus, AM, Brazil

(2) Leônidas e Maria Deane/FIOCRUZ/AM.

(3) Universidade Federal do Amazonas/UFAM

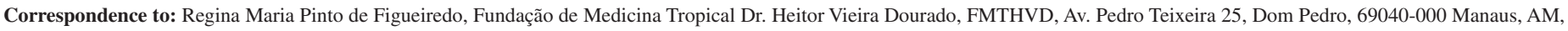
Brasil. E-mail: figueiredormp@yahoo.com.br, rfigueiredo@fmt.am.gov.br 
FIGUEIREDO, R.M.P.; NAVECA, F.G.; OLIVEIRA, C.M.; BASTOS, M.S.; MOURÃO, M.P.G.; VIANA, S.S.; MELO, M.N.; ITAPIREMA, E.F.; SAATKAMP, C.J. \& FARIAS, I.P. - Coinfection of dengue virus by serotypes 3 and 4 in patients from Amazonas, Brazil. Rev. Inst. Med. Trop. São Paulo 53(6): 321-3, 2011.

Table 1

Results of different methods used for identification of dengue virus serotypes co-infecting 4 patients

\begin{tabular}{|c|c|c|c|c|c|c|}
\hline \multirow[b]{2}{*}{ Sample } & \multirow[b]{2}{*}{ Accession numbers } & \multicolumn{2}{|c|}{ RT-PCR and virus isolation } & \multirow{2}{*}{ Genotyping } & \multirow{2}{*}{$\begin{array}{c}\text { MAC-ELISA } \\
\begin{array}{c}\text { Collection } \\
\text { date }\end{array} \\
\end{array}$} & \multirow{2}{*}{ LIRAa } \\
\hline & & $\begin{array}{l}\text { Onset of } \\
\text { symptoms }\end{array}$ & $\begin{array}{l}\text { Collection } \\
\text { date }\end{array}$ & & & \\
\hline AM707 & $\begin{array}{l}\text { JF923865DENV-3 } \\
\text { JF923866 DENV-4 }\end{array}$ & N.I. & $02 / 25 / 2005$ & $\begin{array}{c}\text { (DENV-3 / GIII*) } \\
(\text { DENV-4 / GI) }\end{array}$ & ND & 2.6 \\
\hline AM726 & $\begin{array}{l}\text { JF923879 DENV-3 } \\
\text { JF923880 DENV-4 }\end{array}$ & N.I. & $02 / 28 / 2005$ & $\begin{array}{c}\text { (DENV-3 / GIII*) } \\
\text { (DENV-4 / GI) }\end{array}$ & ND & 2.6 \\
\hline AM750 & $\begin{array}{l}\text { EU127898 DENV-3 } \\
\text { EU127899 DENV-4 }\end{array}$ & $04 / 28 / 2005$ & 05/06/2005 & $\begin{array}{c}\text { (DENV-3 / GIII*) } \\
\text { (DENV-4 / GI) }\end{array}$ & $\begin{array}{l}\text { Negative } \\
05 / 06 / 2005\end{array}$ & 2.6 \\
\hline +AM2220 & JF923873, DENV-4 & $11 / 27 / 2007$ & $11 / 28 / 2007$ & (DENV-4 / GI) & $\begin{array}{l}\text { Positive } \\
12 / 05 / 2007\end{array}$ & 2.8 \\
\hline
\end{tabular}

N.I. = not informed; ND = Test not done; + The sequence of DENV-3 was of poor quality; $*$ The genotypes presented were of highest probability despite the small size of the PCR fragment sequenced; The genotypes were those most likely, although the reliability is not $100 \%$ due to the small size analyzed.

been circulating in a silent cryptic way in northern Brazil in the last few years. In 2010, the LIRA was $1.5 \%$, showing an alarming situation in Manaus which led to the dengue fever outbreak in the first three months of 2011 (unpublished data).

According to the period of the disease, (Table 1) it was possible to observe during convalescence the presence of the DENV by the RT-PCR ${ }^{10}$ method, irrespective of the presence or absence of antibodies.

Nucleotide sequence analysis shows genotype 3 for DENV-3, although the reliability is not $100 \%$ due to the small size analyzed (Table 1), whereas DENV-4 samples were typed as genotype 1, in accordance with previous analyses ${ }^{2}$. Regarding the circulation of DENV-4 of genotype I, causing cases of human infection in Manaus, it is possible that DENV-4 of genotype I has been introduced by international visitors or by imported mosquitoes from Asia ${ }^{2}$. The isolates reported here were from patients with no travel history, which indicates autochthonous infection.

In Brazil, one case of co-infection by DENV- 1 and DENV-2 was reported in a patient with classic dengue fever (DF) from the southeast region, in $2001^{12}$. Another case of co-infection by DENV-2 and DENV3 was reported in 2005 in a patient DF from the northeast region, who recovered without a relapse ${ }^{1}$. During an outbreak of dengue in São José do Rio Preto, in the state of São Paulo, 365 samples showed positive to DENV-3, five samples were positive to DENV-2, and 8 to St. Louis encephalitis flavivirus (SLEV). Among the positive samples, one co-infection was detected between DENV-2 and DENV- $3^{13}$. Hence, co-infection with distinct DENV serotypes during outbreaks may be expected.

The co-infected patients presented benign clinical examinations and recovered without sequel, corroborating with previous reports ${ }^{12}$. Here, we report cases of co-infection by dengue in the state of Amazonas, concurrent with the first reported cases of DENV-4 in Brazil after Roraima 1981-1982. Viral evolution of DENV-4 cases from Manaus should be studied in detail since it is an Asian genotype that has been associated with DHF in the Asian continent.

\section{RESUMO}

\section{Co-infecção pelo vírus dengue 3 e 4 em pacientes da Amazônia brasileira}

A co-infecção natural com os vírus dengue pode ocorre em áreas altamente endêmicas onde diferentes sorotipos têm sido transmitidos por muitos anos. Relatamos aqui quatro casos de co-infecção com DENV-3/ DENV-4 detectados por testes sorológicos e moleculares entre 674 pacientes com febre indiferenciada aguda, atendidos em um centro de medicina tropical de referência da cidade de Manaus, Brasil, entre 2005 e 2010. As análises das sequências obtidas indicaram a presença dos genotipos 3 e 1 para DENV-3 e DENV-4 respectivamente.

\section{ACKNOWLEDGMENTS}

Dr. Luis Tadeu Figueiredo and Dr. Rajendranath Ramasawmy by suggestions.

\section{FINANCIAL SUPPORT}

Conselho Nacional de Desenvolvimento Científico e Tecnológico (CNPq).

\section{REFERENCES}

1. Araújo FMC, Nogueira RMR, Araújo JMG, Ramalho ILC, Roriz MLF, Melo MEL, et al. Concurrent infection with dengue virus type-2 and DENV-3 in a patient from Ceará, Brazil. Mem Inst Oswaldo Cruz. 2006;101:925-8.

2. De Melo FL, Romano CM, de Andrade Zanotto PM. Introduction of dengue virus 4 (DENV-4) genotype I in Brazil from Asia? PLoS Negl Trop Dis. 2009;3:e390.

3. Figueiredo RMP, Thatcher BD, Lima ML, Almeida TC, Alecrim WD, Guerra MVF. Doenças exantemáticas e primeira epidemia de dengue ocorrida em Manaus, Amazonas no período de 1998 -1999. Rev Soc Bras Med Trop. 2004;37:476-9.

4. Figueiredo RMP, Naveca FG, Bastos SM, Melo MN,Viana SS, Mourão MP, et al. Dengue virus type 4, Manaus, Brazil. Emerg Infect Dis. 2008;14:667-9. 
FIGUEIREDO, R.M.P.; NAVECA, F.G.; OLIVEIRA, C.M.; BASTOS, M.S.; MOURÃO, M.P.G.; VIANA, S.S.; MELO, M.N.; ITAPIREMA, E.F.; SAATKAMP, C.J. \& FARIAS, I.P. - Coinfection of dengue virus by serotypes 3 and 4 in patients from Amazonas, Brazil. Rev. Inst. Med. Trop. São Paulo 53(6): 321-3, 2011.

5. Gubler DJ. Dengue and dengue hemorrhagic fever. Clin Microbiol Rev. 1998;11:48096.

6. Guzmán MG, Kouri G, Bravo J. Is sequential infection a risk factor for DHF/DSS? Arthropod-borne Virus Information Exchange. 1986:172-5.

7. Instituto de Medicina Tropical Pedro Kouri. Tecnicas de laboratorio para el diagnostico y la caracterización del vírus dengue. Cidade de Havana: IMT Pedro Kouri; 2001.

8. Klungthong C, Zhang C, Mammen MP Jr, Ubol S, Holmes EC. The molecular epidemiology of dengue virus serotype 4 in Bangkok, Thailand. Virology. 2004:329:168-79.

9. Kuno G, Gómez I, Gubler DJ. Detecting artificial antidengue IgM immune complexes using an enzyme-linked immunosorbent assay. Am J Trop Med Hyg. 1987;36:153-9.

10. Lanciotti RS, Calisher CH, Gubler DJ, Chang GJ, Vorndam AV. Rapid detection and typing of dengue viruses from clinical samples by using reverse transcriptasepolymerase chain reaction. J Clin Microbiol. 1992;30:545-51.
11. Nogueira MB, Stella V, Bordignon J, Batista WC, Borba L, Silva LH, et al. Evidence for the co-circulation of dengue virus type 3 genotypes III and V in the Northern region of Brazil during the 2002-2004 epidemics. Mem Inst Oswaldo Cruz. 2008;103:483-8.

12. Santos CL, Bastos MA, Sallum MA, Rocco IM. Molecular characterization of dengue viruses type 1 and 2 isolated from a concurrent human infection. Rev Inst Med Trop São Paulo. 2003;45:11-6.

13. Terzian ACB, Mondini A, Bronzoni RVM, Drumond BP, Ferro BP, Cabrera SEM, et al. Detection of Saint Louis encephalitis virus in dengue-suspected cases during a dengue 3 outbreak. Vector Borne Zoonotic Dis. 2011;11:291-300.

Received: 11 May 2011

Accepted: 28 September 2011 